\title{
Application of phytoremediation for heavy metal contaminated sites in the South Pacific: strategies, current challenges and future prospects
}

\section{Ivan Diarra, Krishna Kumar Kotra \& Surendra Prasad}

To cite this article: Ivan Diarra, Krishna Kumar Kotra \& Surendra Prasad (2021):

Application of phytoremediation for heavy metal contaminated sites in the South Pacific: strategies, current challenges and future prospects, Applied Spectroscopy Reviews, DOI: 10.1080/05704928.2021.1904410

To link to this article: https://doi.org/10.1080/05704928.2021.1904410

Published online: 19 Apr 2021.

Submit your article to this journal $\pi$

Q View related articles $\asymp$

View Crossmark data $\asymp$ 


\title{
Application of phytoremediation for heavy metal contaminated sites in the South Pacific: strategies, current challenges and future prospects
}

\author{
Ivan Diarra $^{\mathrm{a}}$ (D), Krishna Kumar Kotra ${ }^{\mathrm{b}}$ (D), and Surendra Prasad ${ }^{\mathrm{a}}$ (D) \\ ${ }^{a}$ School of Agriculture, Geography, Environment, Ocean and Natural Sciences (SAGEONS), The University \\ of the South Pacific, Suva, Fiji; ${ }^{b}$ Lecturer in Chemistry, The University of the South Pacific, Emalus \\ Campus, Port Vila, Vanuatu
}

\begin{abstract}
Effectively dealing with hazardous and recalcitrant pollutants such as heavy metals (HMs) has become a global challenge with limited options available for reprieve. This is true for Pacific Island Countries and Territories (PICTs) which have witnessed significant economic transitions and substantial increases hazardous waste depositions. Although several physico-chemical remediation techniques exist, the economic and geographic limitations of PICTs render them impractical for the region. Phytoremediation, a plant-based remediation technology which exploits hyperaccumulator plants to extract, accumulate and/or stabilize HMs, has received significant interest as a sustainable and non-intrusive remediation option. Nonetheless, improving the application and efficiency of phytoremediation programs not only requires a better understanding of the fundamental mechanisms governing $\mathrm{HM}$ accumulation and tolerance in plants, but also demands fast and reliable spectroscopic techniques for in-situ analysis. This review critically examines the current practices in phytoremediation and its prospects for the treatment of HM-contaminated sites in PICTs. We also review the limitations of traditional spectroscopic techniques such as inductively coupled plasma mass spectroscopy/atomic emission spectroscopy (ICP-MS/ $\mathrm{AES}$ ) and the promise of novel techniques such as field portable $\mathrm{X}$-ray fluorescence spectrometry (FP-XRF), atmospheric pressure discharge plasma (APDP) and lab on chip (LOC) in phytoremediation studies.
\end{abstract}

\section{KEYWORDS}

Phytoremediation; phytoextraction; Pacific Islands; heavy metals; spectroscopy; contaminated land management

\section{Introduction}

Although the continuous advancements in agriculture, manufacturing, transportation and mining have all improved human living standards and quality of life, they have also significantly contributed to toxic waste generation with severe environmental consequences. The major concern has been recalcitrant and non-degradable toxicants such as heavy metals (HMs) and their persistence in the environment. Environmental proliferation of trace elements, particularly HMs in terrestrial and marine ecosystems, has been 
reported to elicit numerous health issues and impedes on the overall functioning of the ecosystem [1]. The small and developing island states of the Pacific have not been spared from this menace. Independent studies as well as data from regional bodies such as Secretariat of the Pacific Regional Environmental Program (SPREP) have long highlighted the extent of HM contamination and the long-term potential threats to the region [2]. Although reliable estimates are hard to obtain, available reports suggest that about $1 \%$ of all waste produced in the PICTs are considered hazardous while metal waste produced in the region ranges from $1.9 \%$ in the Fiji Islands to $16.9 \%$ in the Federated States of Micronesia [3]. A classic example of this growing challenge is the asbestos contamination in the Cook Islands. Following the discovery of high levels of asbestos in two school buildings and surrounding topsoil in Rarotonga, Cook Islands, four treatment options were proposed. The first option was encapsulating the contaminated materials and soils on site, the second was removal and disposal of all contaminated materials at a landfill, the third was removal and disposal at an international landfill (likely New Zealand), and lastly, removal and disposal at sea. However, due to the prohibitively high costs (US\$250,000) estimated for removal and disposal of asbestos at the two schools, the low-cost option of onsite confinement by burial ( $3 \mathrm{~m}$ deep with $200 \mu \mathrm{m}$ polythene covering) was selected, despite public disapproval. In total, fifty-four sites scattered around the South Pacific region have been identified and classified as "contaminated" with an estimated US\$110m required for clean-up and remediation [4]. This, along with several other case studies underscore the limitations of small island nations in properly addressing and controlling hazardous waste contamination.

With the projected increase in population and economic activity in the region, hazardous waste contamination is expected to exponentially increase over the next few decades. As such, in the interest of environmental quality and sustainable development, there is clearly an urgent need to elicit and remediate the extent of hazardous contaminants. Despite extensive deployment of physico-chemical remediation technologies in developed countries, technical, logistical and financial limitations have made their application challenging and often impractical, especially in small developing countries [5]. As such, these issues have necessitated the need for comprehensive, practical, cost-effective and sustainable approaches for dealing with hazardous pollutants. Phytoremediation has been the focus of intensive research in the last two decades and is considered to be among the safest, cleanest, cost-effective and least disruptive options for treating sites contaminated with recalcitrant pollutants like HMs [6]. Phytoremediation requires more effort than simply planting vegetation and, with minimal maintenance, assuming that the contaminant will disappear. It requires an understanding of the underlying biochemical processes that need to occur, the selection of suitable plants, and agronomic practices to foster plant growth. Nonetheless, effective application of phytoremediation programs at HM-contaminated sites require accurate assessment of soil and plant materials both pre-and-post treatment, as well as long term monitoring to follow the progress. Several analytical techniques exist for this purpose with notable differences between them in terms of cost and suitability for particular elements. These include traditional and effective detection methods such as inductively coupled plasma mass spectrometry/atomic emission spectrometer (ICP-MS/AES), atomic absorption spectrometry (AAS), anodic stripping voltammetry (ASV), and laser-induced breakdown 
spectrometry (LIBS). However, novel analytical techniques such as lab on chip (LOC) and atmospheric pressure discharge plasma (APDP) offer the possibility of replacing a fully equipped conventional laboratory with compact miniaturized systems, very low sample volumes, real-time analysis, and a quick response for phytoremediation studies. This paper discusses the current global trends for HM for soil remediation as well as a comprehensive assessment of phytoremediation technology as a practical treatment option for contaminated soils with respect to Small Island Developing States (SIDS) in the Pacific. In addition, the techniques, potential benefits and the current challenges facing its deployment are discussed in detail.

\section{Treatment options for environments contaminated with heavy metals}

Over the last few decades, a number of strategies and technologies have been developed and applied to address HM contamination. According to Stegmann et al. [7], contaminated sites may be managed using either of four alternatives; (i) abandonment of the contaminated site, (ii) complete or partial encapsulation of the contaminated site, (iii) excavation and disposal of the contaminated soil followed by landfilling, or (iv) treatment of the contaminated soil in-situ or ex-situ. The first three alternatives do not exactly eliminate the contaminant from the site but rather restrict further spread and prevents human exposure. However, these methods are effective only in small isolated areas and best suited for short term periods. As such, several remediation techniques have been sought and developed in the last three decades to effectively deal with the problem. These techniques consist of chemical, physical, thermal and biological methods which have been broadly classified into ex-situ (off-site) and in-situ (on-site) remediation techniques. Generally, ex-situ remediation techniques require the removal of contaminated media (soil, sediment, water, etc.) for treatment off site and returning the treated media to the original site. Conventional ex-situ remediation methods includes excavation, detoxification and/or destruction of the contaminant physically or chemically, through stabilization, solidification, immobilization, incineration or destruction [8]. In contrast, in-situ remediation techniques are typically conducted on site to either decrease metal bioavailability or separate contaminants from the bulk soil by means of destruction, transformation and/or immobilization of the contaminant, without the need for excavation or transfer of the contaminated media. Although in-situ remediation methods are cheaper due to the lack of excavation and transportation of materials, they are often more time consuming, less controllable, less effective and less efficient at contaminant removal compared to ex-situ options [8]. A comparison between commonly applied soil remediation technologies for heavy metals have been presented in Table 1.

\section{Phytoremediation and mechanisms of application}

As aforementioned, conventional physical and chemical methods of HM removal from a polluted environment are unsuitable at large scales, often costly, and highly intrusive [refer to Wuana and Okieimen [8] for detailed review]. Derived from the Greek word phyto meaning 'plant' and Latin word remedium which means 'to cure an evil', 
Table 1. A comparison of major remediation technologies for heavy metals.

\begin{tabular}{|c|c|c|c|c|c|}
\hline Methods & $\begin{array}{c}\text { Available } \\
\text { technologies }\end{array}$ & $\begin{array}{l}\text { Application } \\
\text { strategy }\end{array}$ & Estimated Duration & $\begin{array}{c}\text { Technical } \\
\text { requirements }\end{array}$ & Cost (\$) \\
\hline \multirow[t]{5}{*}{ Physical } & $\begin{array}{l}\text { Encapsulation/ } \\
\text { Capping/ } \\
\text { Isolation }\end{array}$ & In-situ & $<1$ year & Low & $\$ 22-\$ 74$ per $\mathrm{m}^{3}$ \\
\hline & $\begin{array}{c}\text { Stabilization and } \\
\text { solidification }\end{array}$ & In-situ/Ex-situ & $<1$ year & Medium & $\begin{array}{r}\$ 45-\$ 170 \\
\text { per ton }\end{array}$ \\
\hline & Excavation & Ex-situ & $<0.5$ years & Low & $\begin{array}{l}\$ 270-\$ 460 \\
\text { per ton }\end{array}$ \\
\hline & $\begin{array}{c}\text { Permeable } \\
\text { reactive } \\
\text { barriers }\end{array}$ & In-situ & 10 years & Medium & $\$ 43-\$ 417$ per $\mathrm{ft}^{2}$ \\
\hline & $\begin{array}{l}\text { Electro-kinetic } \\
\text { remediation }\end{array}$ & In-situ & $1-3$ years & High & $\$ 20-\$ 100$ per $\mathrm{m}^{3}$ \\
\hline \multirow[t]{3}{*}{ Chemical } & $\begin{array}{l}\text { Chemical } \\
\text { oxidation } \\
\text { and reduction }\end{array}$ & In-situ & $<1$ year & Medium & $\begin{array}{l}\$ 31-175 \$ \\
\text { per gallon }\end{array}$ \\
\hline & Soil flushing & In-situ & $1-3$ years & High & $\begin{array}{l}\$ 150-\$ 250 \\
\text { per ton }\end{array}$ \\
\hline & Soil washing & Ex-situ & $<0.5$ years & High & $\$ 6-\$ 200$ per $\mathrm{m}^{3}$ \\
\hline \multirow[t]{3}{*}{ Thermal } & Vitrification & In-situ/Ex-situ & $<1$ year & High & $\begin{array}{l}\$ 355-\$ 460 \\
\text { per ton }\end{array}$ \\
\hline & Desorption & Ex-situ & $<0.5$ years & Medium & $\$ 44-\$ 252$ per $\mathrm{m}^{3}$ \\
\hline & Incineration & In-situ/Ex-situ & $<1$ year & Low & $\begin{array}{c}\$ 914-\$ 1540 \\
\text { per } \mathrm{m}^{3}\end{array}$ \\
\hline Bioremediation & $\begin{array}{l}\text { Bioaugmentation } \\
\text { Biostimulation } \\
\text { Mycoremediation } \\
\text { Phytoremediation }\end{array}$ & In-situ/Ex-situ & $0.5-6$ years & Low-Medium & $\$ 10-\$ 100$ per $\mathrm{m}^{3}$ \\
\hline
\end{tabular}

phytoremediation refers to a suite of technologies which exploit plants, vegetation and associated microbiota, soil amendments, and agronomic techniques to remove, contain, or render environmental contaminants harmless. Phytoremediation is potentially applicable to treat some of the most significant contaminants, such as petroleum hydrocarbons, chlorinated solvents, HMs, radionuclides, nutrients, pentachlorophenol (PCP), and polycyclic aromatic hydrocarbons (PAHs). Compared to conventional technologies (soil capping, soil washing, vitrification, etc.) developed for small, heavily contaminated sites, phytoremediation is better suited for large volumes of soil containing low to moderate levels of HMs due to the ease of application and the cost-effective nature [8]. As a relatively new technology, phytoremediation is still largely in its trial stages with limited field applications so far; however, investigations on the subject continue to present promising results [9]. Phytoremediation mechanisms applicable to HM-contaminated soils include phytostabilization, phytovolatization, rhizofiltration and phytoextraction.

Phytostabilization involves the establishment of a plant cover on the surface of the contaminated sites with the aim of reducing the mobility of contaminants within the vadose zone through accumulation by roots or immobilization within the rhizosphere, thereby reducing off-site contamination. Since metals with different oxidation states possess and display diverse toxicity, several plants are able to convert these metals into less toxic states by releasing redox enzymes. For instance, $\mathrm{Cr}(\mathrm{VI})$ can be converted into $\mathrm{Cr}$ (III) which is less toxic and less mobile in the soil [10]. While phytostabilization is minimally disruptive (no contaminated secondary waste), it is regarded as a temporary measure for the containment of pollutants rather than a long-term remedial option. Meanwhile, phytovolatilization is the process whereby plants absorb volatile organic 
compounds (VOCs), convert them into less toxic vapors and release them into the atmosphere via transpiration. As such, phytostabilization is suited for HMs such as Se, $\mathrm{Hg}$ and As which can exist as gaseous species in the environment. Several plant species including A. thaliana, B. juncea and C. canescens have been shown to possess the ability to extract HM and convert them into a gaseous species which are released into the atmosphere [11]. However, phytovolatization remains controversial since the contaminants released into the atmosphere can be re-deposited back into the soil after a while, and therefore not a practical long-term solution. In contrast, rhizofiltration primarily employs the roots of certain terrestrial or aquatic plant species to absorb, concentrate, and precipitate HMs from contaminated water and aqueous waste sources. By using rhizofiltration, numerous plant species have been found to effectively remove HMs such as $\mathrm{Pb}, \mathrm{Cd}, \mathrm{Cu}, \mathrm{Ni}, \mathrm{Zn}$, and $\mathrm{Cr}$, which are primarily held within the roots and has been proven to be suitable for the treatment of acid mine drainage, partially treated industrial discharges and agricultural runoff, as well as low-level radioactive contaminants from liquid streams [12].

Phytoextraction involves the utilization of specific plants to transport and concentrate metals from the environment to the harvestable parts of the root and the aerial tissues. Species considered suitable for phytoextraction generally meet the following criteria: (i) metallotolerant to high HMs concentrations, (ii) rapid growth and high biomass production, and (iii) effective accumulation of metals in foliar parts. Among, phytoremediation technologies, phytoextraction has received increasing attention from researchers not only for its public appeal, but also for the substantial economic opportunity it presents [13]. Two approaches have been proposed for HM phytoextraction; continuous or natural phytoextraction and chemically enhanced phytoextraction. Continuous or natural phytoextraction employs natural hyperaccumulators with exceptional metal-accumulating capacity; however, such hyperaccumulators may tend to be slow growing, produce low biomass, and take years or decades to effectively clean-up sites. Chemically assisted phytoextraction (chelate-enhanced phytoextraction) tries to address these shortfalls by artificially inducing HM accumulation in plants through the application of amendments such as chelating agents which increase HM solubility and bioavailability in soil (Figure 1). Chelator supplementation has been shown to increase metal accumulation by $10-100$ fold [14].

\section{Plant mechanisms for coping with metal toxicity}

Millions of years of strong selective pressures on metalliferous soils have resulted in metallophytes, endemic plant species with biological adaptations to restrict, tolerate, or thrive on toxic metalliferous soils (Figure 2). Baker [15], classified metallophytes into three basic categories based on their leaf:root metal concentration and strategies for growing on metalliferous soil. The first group are metal excluders, which actively prevent importing metals to aerial organs, thus maintaining low metal concentrations by mostly restricting metal uptake to the roots. The second group are known as metal indicators, referring to plant species which actively accumulate metals in their aerial tissues to reflect the concentration of that metal in the soil, thus displaying a linear relationship between metal concentration is plants and soil. 


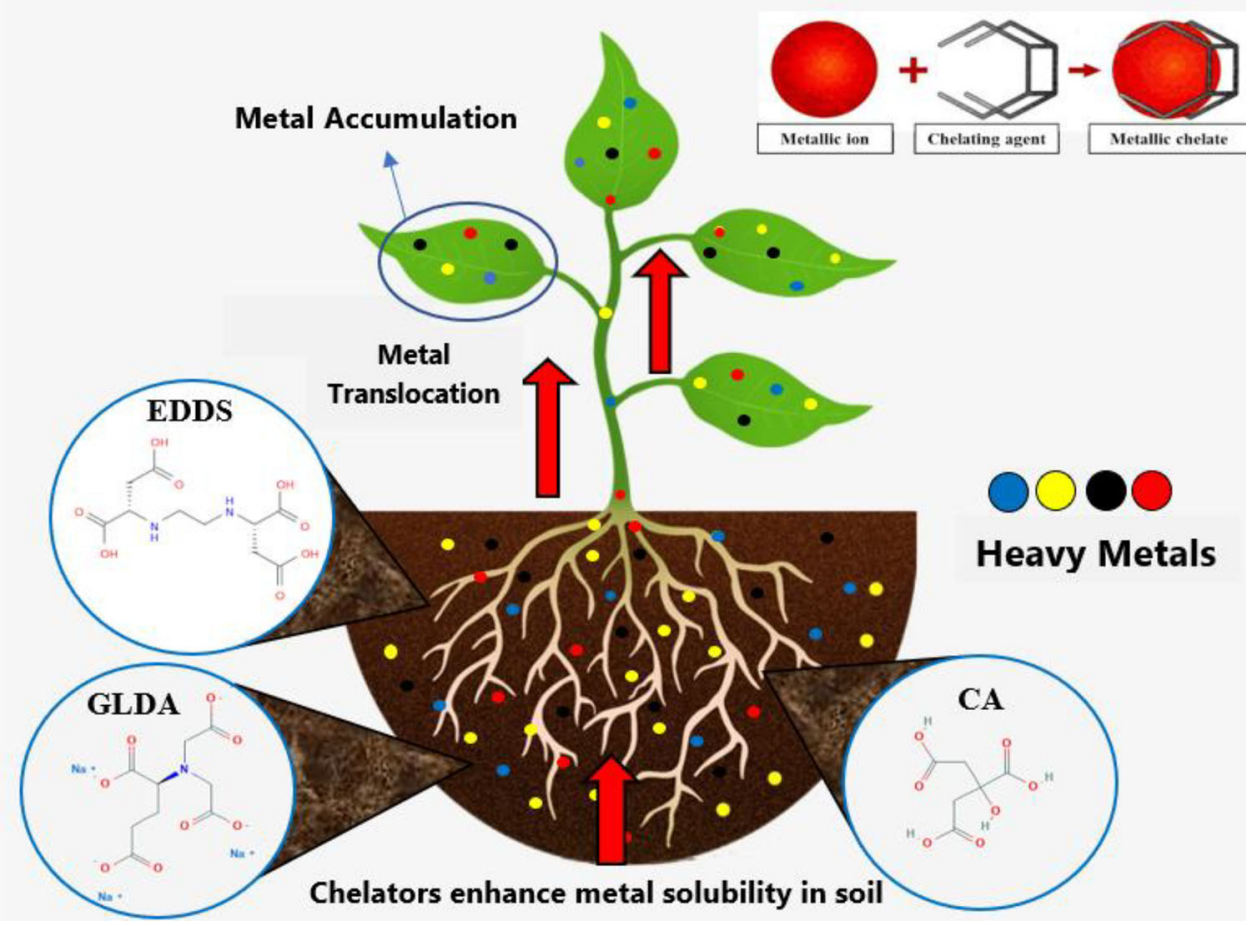

Figure 1. A representation of chelate assisted phytoextraction (EDDS: Ethylenediamine-N, N'-disuccinic acid, GLDA: Tetrasodium Glutamate Diacetate, CA: Citric acid).

The last group of metallophytes are termed metal hyperaccumulators, described as plants that when growing on native soils can concentrate $>10 \mathrm{mg} \mathrm{g}^{-1}$ (1\%) $\mathrm{Mn}$ or $\mathrm{Zn}$, $>1 \mathrm{mg} \mathrm{g}^{-1}(0.1 \%) \mathrm{As}$, Co, Cr, Cu, Ni, Pb, Sb, Se or Tl, and $>0.1 \mathrm{mg} \mathrm{g}^{-1}(0.01 \%) \mathrm{Cd}$ in their aerial organs, without suffering phytotoxic damage. Three basic hallmarks distinguish hyperaccumulators from related non-hyperaccumulating taxa: a strongly enhanced rate of HM uptake, a faster root-to-shoot translocation, and a greater ability to detoxify and sequester HMs in leaves. Although a distinct feature, hyperaccumulation also relies on hypertolerance, an essential key property allowing plants to avoid HM poisoning, to which hyperaccumulator plants are as sensitive as non-hyperaccumulators. About 450 angiosperm species have been identified so far as HM hyperaccumulators, accounting for less than $0.2 \%$ of all known species, however, new reports on such plants continue to accrue. The concept of metal hyperaccumulator was first described by Jaffré et al. [16] for nickel accumulating species in New Caledonia and since then, numerous discoveries and reports of metal hyperaccumulators have been made in PICTs. New Caledonia in particular is a major reservoir of Ni hyperaccumulators and hosts about $65 \mathrm{Ni}$ hyperaccumulator taxa scattered among twelve plant families and about fifty plant species (Table 2). This is attributed to the island's unique geological history which has made it rich in serpentine soils which are low in phosphorus, potassium, calcium and high in HMs such as $\mathrm{Ni}, \mathrm{Mg}, \mathrm{Mn}, \mathrm{Cr}$ and $\mathrm{Co}$ [17]. As a result, the islands harbor a rich flora ( 2145 species) of which approximately $80 \%$ are endemic with particular adaptations to these challenging edaphic conditions. 


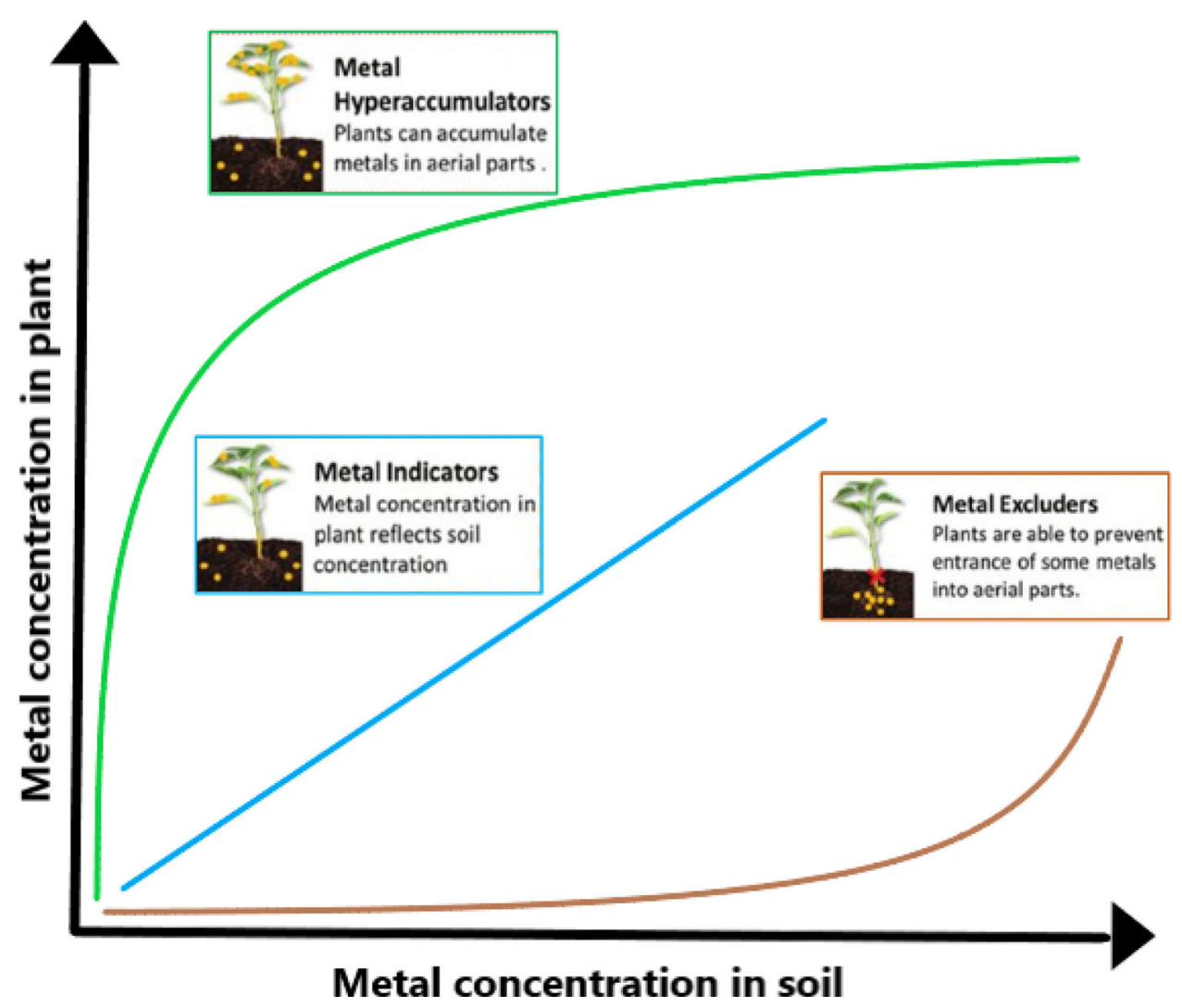

Figure 2. Different plant responses to bioavailable heavy metals in the soil.

Table 2. Native metal hyperaccumulators in New Caledonia [adapted from Morel et al. [18]].

\begin{tabular}{lllc}
\hline Family & \multicolumn{1}{c}{ Plant species } & Metals & Maximum concentrations recorded $\left(\mathrm{mg} \mathrm{kg}^{-1}\right)$ \\
\hline Apocynaceae & Alyxia rubricaulis & $\mathrm{Mn}$ & $11,500-14,000$ \\
Celastraceae & Maytenius bureaviana & $\mathrm{Mn}$ & 33,750 \\
& Maytenus pancheriana & $\mathrm{Mn}$ & 16,370 \\
& Maytenus serbertiana & $\mathrm{Mn}$ & 22,500 \\
Clusiaceae & Garcinia amplexicaulis & $\mathrm{Mn}$ & 10,500 \\
Cunoniaceae & Geissois pruinosa & $\mathrm{Ni}$ & 34,000 \\
Euphorbiaceae & Phyllantus (42 taxa) & $\mathrm{Ni}$ & $1090-60,170$ \\
& Phyllanthus serpentinus & $\mathrm{Ni}$ & 3800 \\
Flacourtiaceae & Homalium (7 species) & $\mathrm{Ni}$ & $1160-14,500$ \\
& Xylosma (11 species) & $\mathrm{Ni}$ & $1000-3750$ \\
Myrtaceae & Eugenia clusioides & $\mathrm{Mn}$ & 10,880 \\
Proteaceae & Macadamia Neurophylla & $\mathrm{Mn}$ & 55,200 \\
& Beaupreopsis paniculata & $\mathrm{Mn}$ & 12,000 \\
& Macadamia angustifolia & $\mathrm{Mn}$ & 11,590 \\
Poaceae & Kerniadecia elliptica & $\mathrm{Al}$ & 15,600 \\
Rubiaceae & Cenchrus echinatus & $\mathrm{Zn}$ & 350 \\
Sapotaceae & Psychotria douarrei & $\mathrm{Ni}$ & 47,500 \\
& Pycnandra acuminate & $\mathrm{Ni}$ & 17,750 \\
Violaceae & Sebertia acuminate & $\mathrm{Ni}$ & 11,700 \\
\hline
\end{tabular}




\section{Factors affecting phytoextraction}

Several factors affect the uptake mechanism of HMs by plants and their subsequent understanding can greatly enhance the uptake performance by plants. The success of a phytoextraction program depends upon the identification of suitable plant species that can hyperaccumulate HMs and produce large amounts of biomass using established crop production and management practices. Some important criteria in selecting plant species for phytoremediation are (i) the level of tolerance to the metals at the concerned site, (ii) the HM accumulation and translocation potential of the plant, (iii) high growth rate and aboveground biomass yield; which provides more area for the uptake and storage of HMs, (iv) tolerance to weather extremes including drought and flooding, (v) tolerance to high $\mathrm{pH}$ and salinity, (vii) root characteristic and depth of the root zone, and (viii) easily harvestable. The root zone also plays an important role in phytoextraction by absorbing HM contaminants and storing or metabolizing them within the plant tissue. In addition, root exudates consisting of a suite of small and high molecular weight organic as well as inorganic compounds can change rhizosphere $\mathrm{pH}$ and increase heavy metal solubility and contribute to the degradation of contaminants in the soil [19]. Beyond plant selection, metal bioavailability in the soil is yet another crucial factor in the phytoextraction process. Soil metal fractions generally exists in three forms; available, unavailable, and exchangeable fractions. Bioavailable metals exist in soil solution as free metal ions and soluble metal complexes, and therefore can be adsorbed to inorganic soil constituents at ion exchange sites. Metal (M) bioavailability in soils is directly proportional to the concentration $(\mathrm{C})$ in soil solution, $(\mathrm{M} \propto \mathrm{C})$. Bioavailability is controlled by both external (soil-associated factors) and internal (plant-associated factors) such as the presence of chelating agents, the soil $\mathrm{pH}$, and microbial activity, as well as the binding of heavy metals to soil particles [20]. Certain HMs including $\mathrm{Cd}, \mathrm{Ni}, \mathrm{Zn}$, As, Se and $\mathrm{Cu}$ occur mainly in exchangeable, readily bioavailable forms, whereas $\mathrm{HMs}$ such as $\mathrm{Pb}$ and $\mathrm{Cr}$ occur as soil precipitates which are a less bioavailable form. For example, Xian and In Shokohifard [21] demonstrated that when soil $\mathrm{pH}$ values decreased from 7.0 to 4.55, the levels of $\mathrm{Cd}, \mathrm{Zn}$, and $\mathrm{Pb}$ in exchangeable form increased. Therefore, the manipulation of soil properties through the amendment of fertilizer, $\mathrm{pH}$ and salinity adjustment, etc. is necessary to enhance HM phytoextraction.

\section{Phytoextraction efficiency}

Three key factors determine the metal accumulation efficiency of plants, namely: bioconcentration factor (BCF), translocation factor (TF), and biomass production. BCF describes the ability of a plant to absorb metals from the soil while, the TF, also called shoot-root quotient, describes a plant's ability to translocate metals from roots to the aboveground biomass (shoots, stems, leaves and flowers). BCF and TF screening are necessary to select and categorize plants either as indicators, excluders or hyperaccumulators. Plants with $\mathrm{BCF}$ and TF greater than one $(>1)$ point to an efficient metal transport system present in the plant, and are considered suitable in root to shoot metal translocation. In contrast, plants with $\mathrm{TF}$ values below one $(<1)$ indicate insufficient metal transfer suggesting that such plants accumulate metals in the roots and rhizomes much greater than in aboveground structures [22]. Table 3 presents a list of commonly 


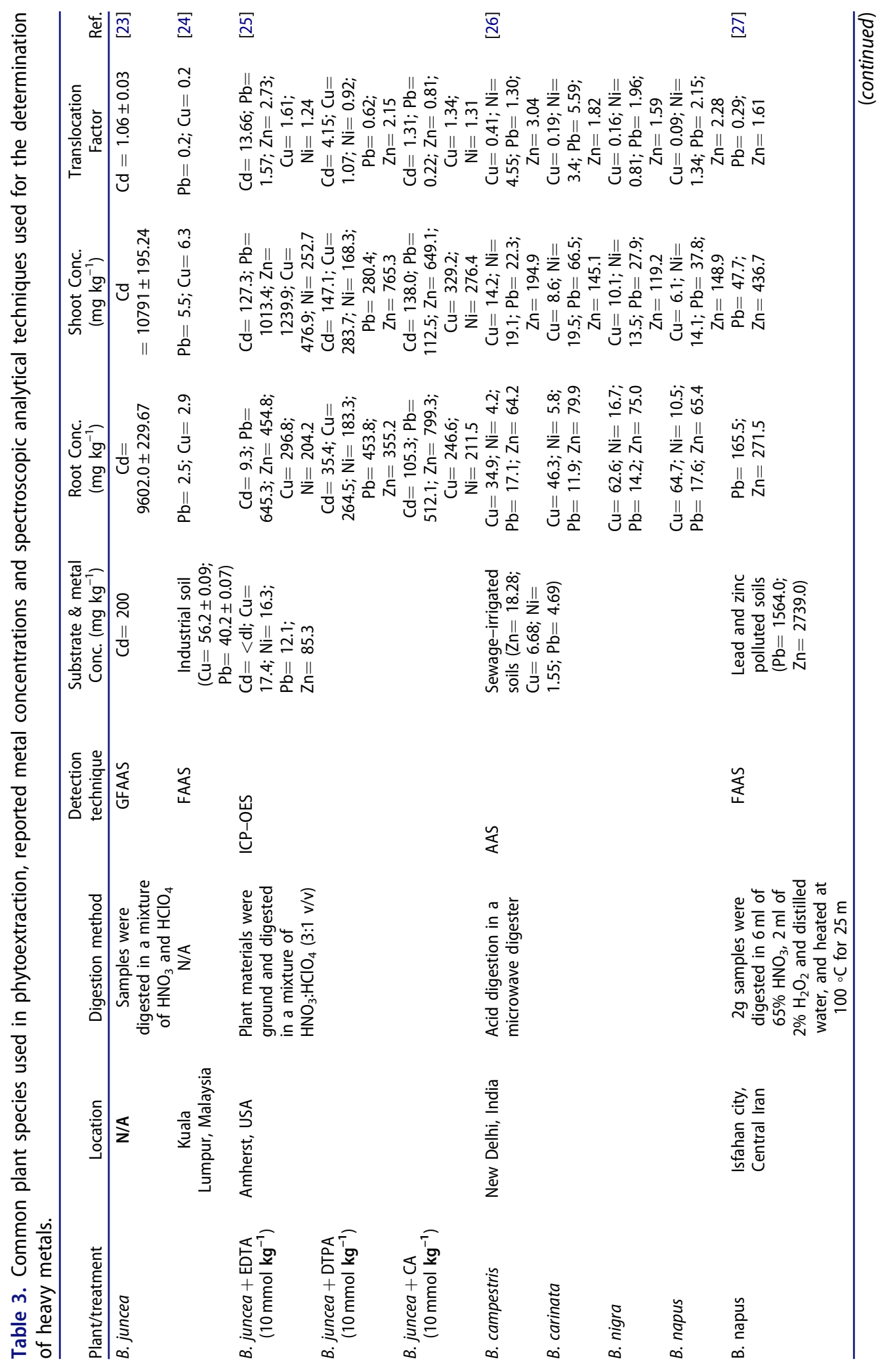




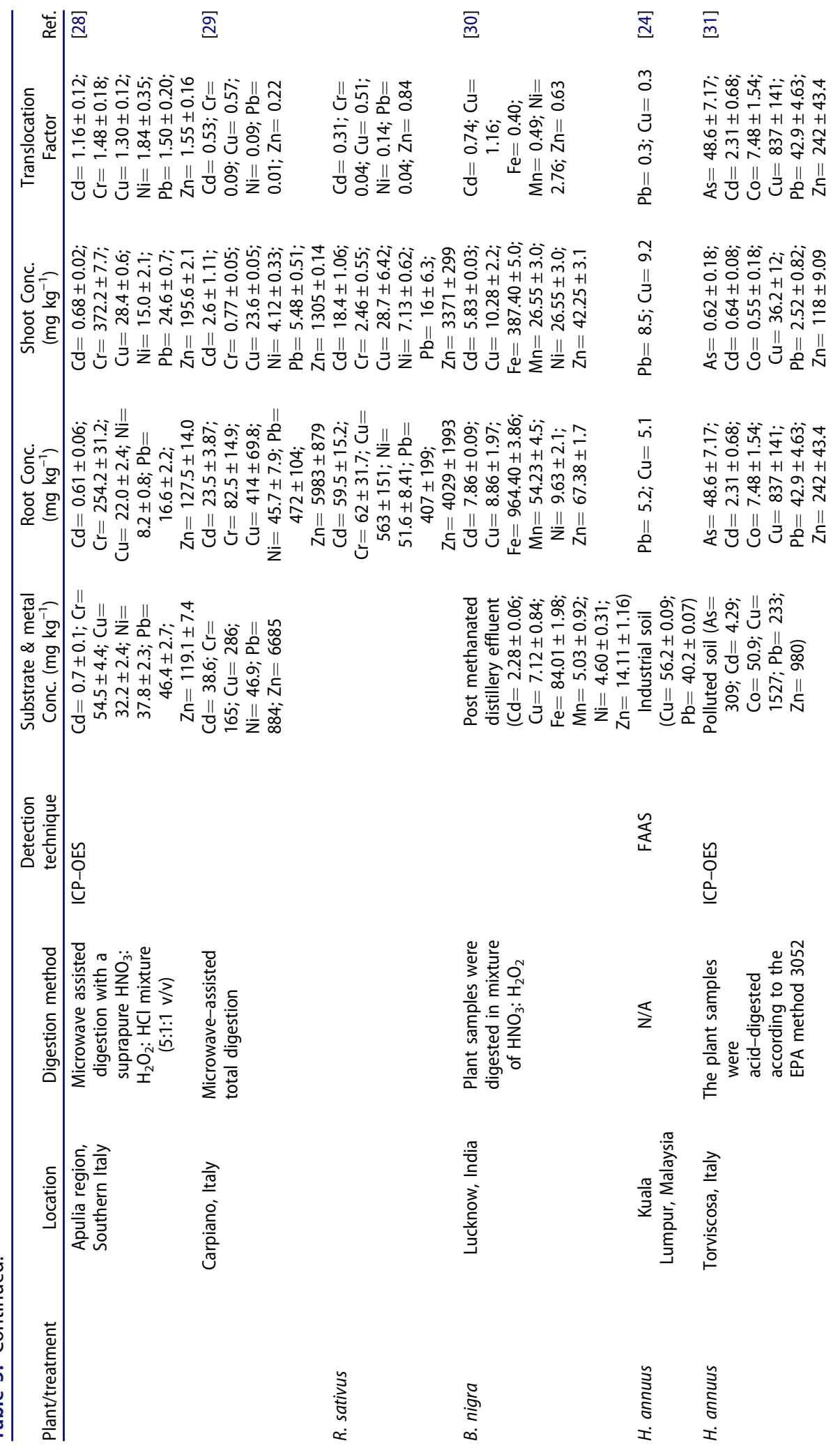




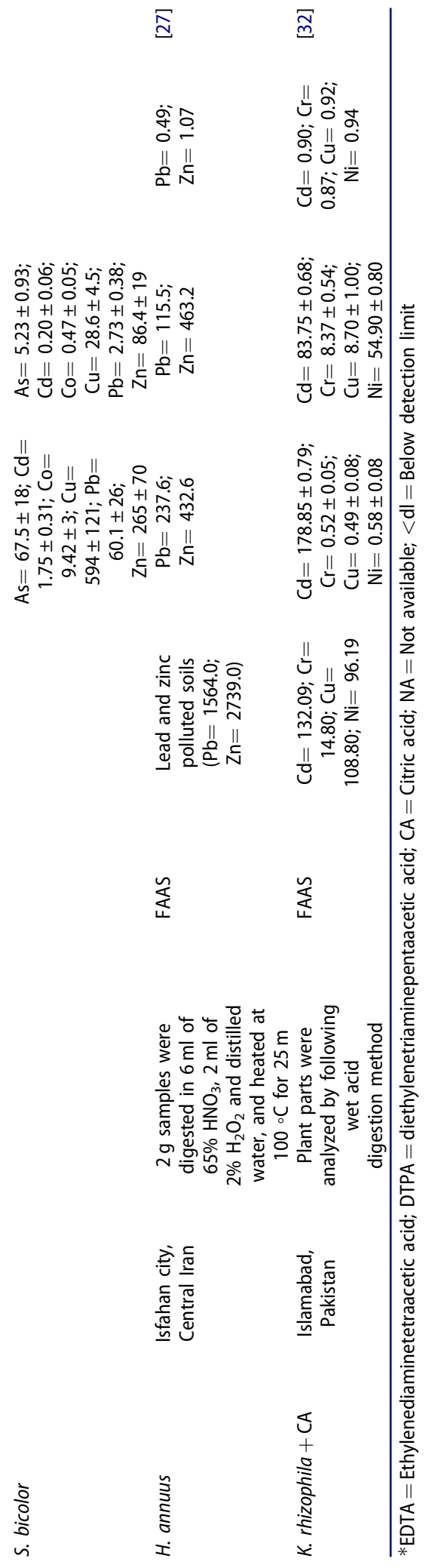


used hyperaccumulators in phytoextraction, their reported TF values and spectroscopic analytical techniques used for the determination certain HMs.

Phytoextraction projects are best assessed based on the quantity of HMs removed from the soil compared to the total amount present and the total time needed for remediation. To attain a reasonable decrease of metal concentration in the soil profile over a certain depth, a certain metal amount has to be removed, calculated using Equation (1); where $\mathrm{A}$ is the amount of metal to be removed per hectare $\left(\mathrm{mg} \mathrm{ha}^{-1}\right), \mathrm{V}$ is soil volume $\left(\mathrm{m}^{3} \mathrm{ha}^{-1}\right), \mathrm{D}$ is soil density $\left(\mathrm{kg} \mathrm{m}^{-3}\right)$, and $\mathrm{CV}$ is the predefined concentration decrease $\left(\mathrm{mg} \mathrm{kg}^{-1}\right)$.

$$
\mathrm{A}=\mathrm{V} \times \mathrm{D} \times \mathrm{CV}
$$

As the total extracted metal amount is the product of plant biomass and tissue metal concentration, the time needed to achieve the predefined soil concentration decrease is calculated using Equation (2), where $\mathrm{T}$ is the time (years), $\mathrm{P}$ is the plant metal concentration (mg kg ${ }^{-1}$ dry mass), and $\mathrm{B}$ is the annual biomass production ( $\mathrm{kg}$ dry mass ha ${ }^{-1} \mathrm{yr}^{-1}$ ).

$$
\mathrm{T}=\frac{\mathrm{A}}{\mathrm{PB}}
$$

\section{Spectroscopic analytical methods in phytoremediation}

Reliable environmental monitoring of HM pollutants and application of phytoremediation programs usually require 'bulk and extensive' analyses of soil, water and biological materials. Such extensive studies are required to determine the most applicable remediation technique and enable the continuous monitoring of HMs in soil and plant materials in order to follow the results and efficacy of the applied technique. Consequently, it is essential that the analytical procedures employed for environmental monitoring and phytoremediation assessment are not only reliable, fast, cheap, reproducible and easily applicable, but require simple sample preparation. While numerous spectroscopic analytical techniques for elemental determination exists, notable differences exist between them in terms of cost, technicality, sample preparation, detection limits, and suitability for particular elements. Some of these differences are discussed in Table 4.

Until recently, atomic absorption spectrophotometry (AAS), specifically flame (FAAS), hydride generation (HG-AAS) and graphite furnace (GF-AAS) have been considered 'workhorses' for HM determination in phytoremediation studies due to their relative cost-effectiveness, simple operation and high precision [33]. However, the use of inductively coupled plasma mass spectrometry/atomic emission spectrometer (ICP-MS/AES) have become routine for trace metal studies due to their high sensitivity, wide dynamic linear range, multielement capability, good reproducibility, and fewer chemical interferences. Most conventional spectroscopic techniques for HM determination in environmental samples (water, soil and plants) requires prior sample dissolution (for total destruction of the matrix). This can be a lengthy and arduous process and occasionally restricts the application of certain analytical procedures in environmental studies and quality control processes. Dry ashing (involving combustion of the sample) and wet digestion (involving digestion with strong acids) have often been employed to destroy the biological materials and deliquesce the analytes in such 


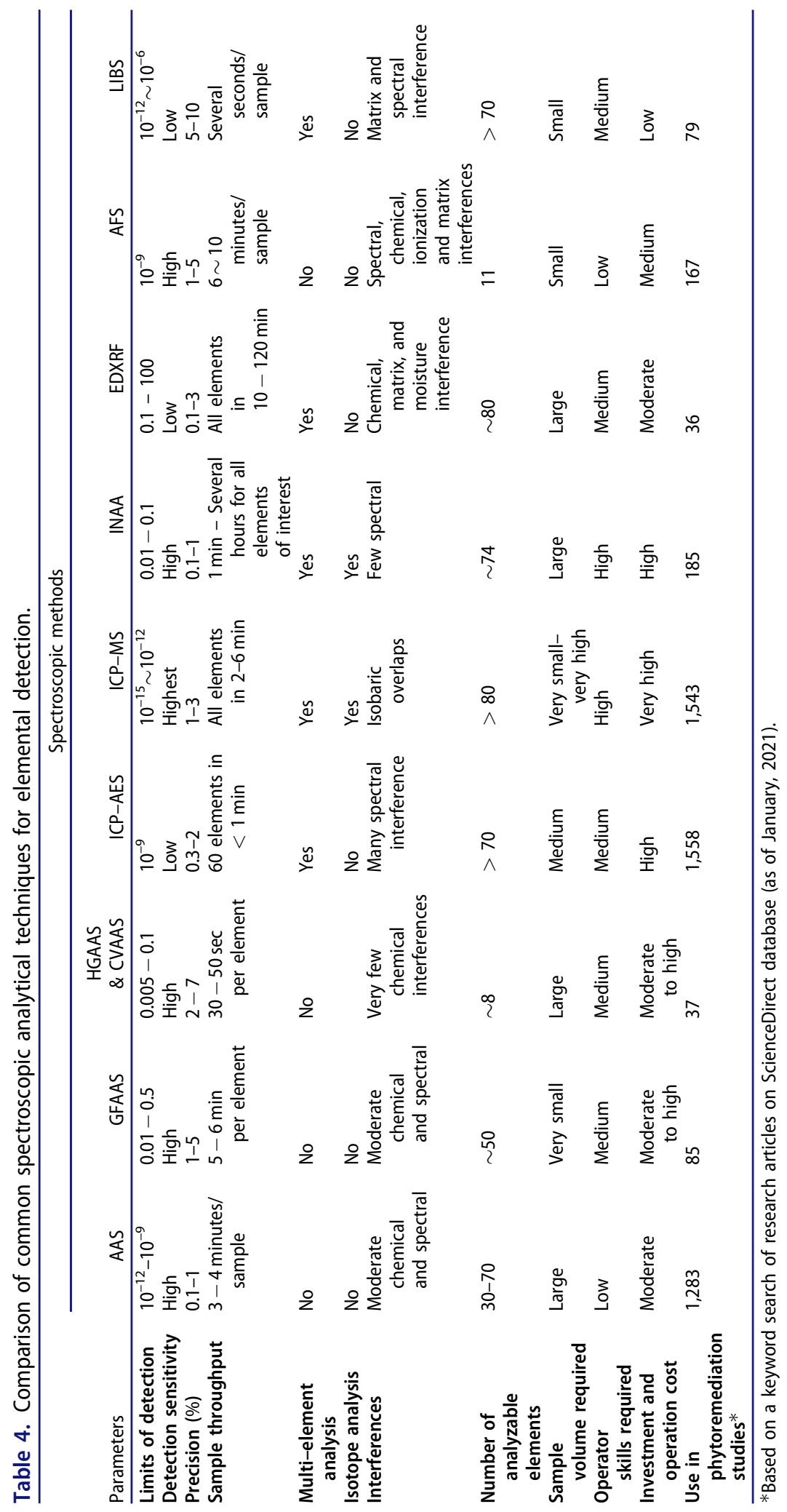


matrices [34]. In comparison to dry ashing methods, wet digestion procedures offer an extensive range of options, contingent on the choice of reagents as well as the instruments utilized [34]. Typically, the challenge lies in the wet digestion of biological samples containing silicon which require the supplementation of hydrofluoric acid to achieve complete matrix dissolution. Over the past two decades, conventional open systems (digestions at atmospheric pressure) using typical sources of heating (e.g., sand baths and hot plates) have been gradually replaced with closed vessel digestion procedures using microwave ovens. Microwave assisted digestion significantly decreases cross-contamination, the digestion duration and volume of reagents used, while preventing the loss of volatile elements such as $\mathrm{Hg}$ and $\mathrm{Cd}$ [34]. Comparative analysis of microwave digestion procedure and open acid digestion have shown that the former offered better precision and recovery values for HM analysis in organic samples [35, 36]. In summary, conventional analytical techniques are not only reliant on large, expensive and complicated instrumentation but require hazardous reagents for sample preparation, therefore limiting their use to laboratory settings.

Nonetheless, HM detection techniques that decrease or eliminate matrix destruction, facilitate direct, easy and rapid determination of ultra-trace heavy metals in solid samples are becoming increasingly attractive and popular, particularly for field studies [37]. Detection techniques such as instrumental neutron activation analysis (INAA), photoacoustic spectroscopy, and laser-induced breakdown spectroscopy (LIBS), have been employed in phytoremediation studies as they facilitate multi-elemental analysis on the tissue and cellular level $[38,39]$. LIBS offers rapid detection and real-time monitoring; however, further improvement and optimization is needed to improve its stability, reduce interference, accuracy, and sensitivity of the spectrum, and improve detection under various conditions [39]. In addition, voltametric methods such as square wave anodic stripping voltammetry (SWASV) have been employed to evaluate the HM phytoremediation of the aquatic plant L. minor, providing a cost effective and portable system for in-situ HM monitoring [40]. Similarly, X-ray fluorescence-based techniques including micro-proton induced X-ray emission (micro-PIXE) spectroscopy, energy dispersive X-ray fluorescence (EDXRF), wavelength dispersive XRF (WDXRF) and total reflection X-ray fluorescence (TXRF) have gained prominence in phytoremediation studies for offering high accuracy, direct and multi-element analysis with little or no sample preparation $[41,42]$. In addition, field portable X-ray fluorescence spectrometry (FP-XRF) enables real-time in-situ analysis due to their portability and have been found to provide high quality data for HM screening in soil and plants [42]. Nečemer et al. [41] critically evaluated INAA, AAS, and X-ray fluorescence-based techniques including micro-PIXE, EDXRF and TXRF in phytoremediation and plant biology studies and concluded that EDXRF offered the possibility of performing qualitative, semi-quantitative and quantitative determinations at a wide dynamic range. The simplicity in sample preparation makes XRF techniques among the cheapest analytical techniques especially suitable for soil and plant material analysis.

Meanwhile, advancements in spectroscopy and analytical techniques continue to show great promise by providing innovative solutions to the challenges and limitations facing traditional analytical methods. For instance, Laser ablation (LA) and glow discharge (GD) have been successfully coupled to traditional techniques such as atomic 
absorption spectrometry (GD-AAS), atomic fluorescence spectrometry (GD-AFS), optical emission spectrometry (GD-OES) and mass spectrometry (GD-MS and LA-ICP-MS) to overcome the traditional challenges in sample preparation [37]. Portable and low-cost systems such as atmospheric pressure discharge plasma (APDP) technology have also drawn considerable research interest [43]. APDP technology enables plasma generation at atmospheric pressure and open-air environments, thus, offering the possibility for elemental analysis in liquid, gas, and solid phases. In plasma, heavy metal compounds or ions can be atomized and excited leading to the radiation of AES, which is the principle behind ICP-AES and LIBS for HM detection. In contrast to low-pressure plasma systems, APDP technology abandons the expensive vacuum system, simplifies the experimental equipment, and reduces the production cost. It is emerging as an ideal technique for trace element analysis and provides excellent potential in real-time, in-suit, and on-line analysis [43]. Significant developments in integrated circuit technology have also given rise to miniaturized laboratory platforms often called lab on chips (LOC), fully capable of chemical analysis. Their various advantages such as the possibility of replacing a fully equipped conventional laboratory, very low consumption of reagent and sample volumes, compactness, low-cost fabrication, real-time analysis, and a quick response toward the target compound/s, makes them ideal for environmental studies [44]. Incorporating geographic information system (GIS), geostatistics, spatial autocorrelation theory, and spectral sensing based monitoring for rapid and efficient visualization and analysis of spatial problems of large phytoremediation areas is also gaining prominence [45].

\section{Advantages and limitations of phytoremediation}

As a novel technology, phytoremediation provides several benefits over conventional techniques of remediation. Phytoremediation has great public appeal and is regarded as an environmentally friendly, esthetically pleasing and a 'green' approach for treating contaminated soil in-situ. In addition, the technology requires little energy input (solar driven) and causes minimal environmental disturbance. In contrast to disruptive remediation technologies such as incineration, thermal vaporization, or solvent washing, which fundamentally destroy the biological component of the soil and drastically alter its chemical and physical properties, phytoremediation involves little to no physical modification of the environment, leaving an improved and functional soil ecosystem [8]. In terms of costs, phytoremediation technologies are also a significantly cheaper alternative to conventional remediation methods which often involve huge operational and energy costs as well as costly chemicals/solvents and materials [46]. Phytoremediation is also applicable for a wide range of hazardous contaminants such as HMs, PAHs, radionuclides as well as organic contaminants with little or no modification. Phytoremediation technologies such as phytoextraction and rhizofiltration are also suitable for treating large contaminated areas at approximately one-tenth the cost of currently adopted technologies [47]. An added advantage of phytoremediation is the generation of recyclable metal-rich plant residue which could serve as fertilizer, or incinerated to generate bioenergy. 
Table 5. The advantages and disadvantages currently facing phytoremediation technologies.

\begin{tabular}{|c|c|c|}
\hline & Advantages & Disadvantages \\
\hline 1 & Applicable both in-situ or off-situ & $\begin{array}{l}\text { Takes several years to effectively remediate } \\
\text { contaminated sites. }\end{array}$ \\
\hline 2 & $\begin{array}{l}\text { Environmentally friendly, publicly } \\
\text { appealing, and socially accepted. }\end{array}$ & $\begin{array}{l}\text { Limited by root depth, solubility and } \\
\text { bioavailability of the contaminant. }\end{array}$ \\
\hline 3 & $\begin{array}{l}\text { Cheaper than conventional } \\
\text { remediation methods. }\end{array}$ & Restricted to sites with low contamination. \\
\hline 4 & Solar driven - less energy requirements. & $\begin{array}{l}\text { Harvested plant biomass requires proper } \\
\text { disposal as hazardous waste. }\end{array}$ \\
\hline 5 & Easy to implement and maintain. & $\begin{array}{l}\text { Poor handling of waste may result in } \\
\text { ecological exposure. }\end{array}$ \\
\hline 6 & $\begin{array}{l}\text { Minimally disruptive and improves soil } \\
\text { functionality. }\end{array}$ & $\begin{array}{l}\text { May lead to the introduction of } \\
\text { invasive species. }\end{array}$ \\
\hline 7 & Suitable for large contaminated areas. & $\begin{array}{l}\text { Highly dependent on environmental and } \\
\text { climatic factors as well as } \\
\text { soil-plant chemistry. }\end{array}$ \\
\hline
\end{tabular}

Nevertheless, several challenges currently limit the application and success of phytoremediation technologies. Compared to other traditional clean-up techniques such as excavation, disposal and incineration which take only weeks to months, phytoremediation largely depends on plant growth rate and growing seasons and may take considerably longer to effectively ameliorate a site. As such it is restricted to remote/isolated areas and unsuitable for locations that pose acute hazards to human and other ecological receptors. Additionally, environmental and soil-plant factors such as growing time, climate, root depth, soil chemistry, and high contamination level, strongly limit the plant species that can be used as well as the success of phytoremediation [48]. Phytoremediation also necessitates that contaminants are in contact with the root zone of the plants and as such, treatment is generally limited to sites with shallow contamination less than one meter from the surface. In addition, hyperaccumulators can only accumulate about $0.2 \%$ (dry weight) for highly toxic elements ( $\mathrm{Cd}, \mathrm{Pb}$ ) and about $2 \%$ for less toxic elements like $\mathrm{Zn}, \mathrm{Ni}$ and $\mathrm{Cu}$ [49] and therefore only applicable to sites with relatively low HM concentrations. Since the harvested biomass post-remediation is classified as a hazardous waste, disposal or recycling must be in accordance with applicable regulations or risk ecological exposure and inadvertent ingestion by animals and insects [50]. In addition, the introduction of non-native species for phytoremediation purposes may lead to invasivity and threaten local biodiversity. The advantages and disadvantages of phytoremediation technologies are further summarized in Table 5.

\section{Current status and future prospects of phytoremediation in PICTs}

Although a scarcity of research into plant based environmental remediation technologies in PICTs currently exists, a few authors including Rungwa et al. [51] have highlighted the potential value of phytoremediation for the amelioration of contaminated sites in the region. Among the studies and trials which have explored the use of plants in ameliorating contaminants in the Pacific Islands, the bulk have been small lab-based trials. Mani et al. [52] evaluated the phytoremediation capability of B. rapa (Chinese Cabbage) on sewage samples obtained from the Kinoya Waste-Water Treatment Plant in Fiji and observed that bioavailable metal uptake $(\mathrm{Cu}, \mathrm{Cd}, \mathrm{Zn}$ and $\mathrm{Mn})$ was limited to leaves and 
stems while $\mathrm{Ni}$, despite being highly mobile, was undetected due to minute concentrations in the sewage sludge. Phytoremediation has also been explored for the reclamation and restoration of some of the many abandoned mine sites and wastes in the region. For instance, Ko et al. [53] investigated the efficiency of B. juncea in the removal of solubilized As from soil and mine tailings in Fiji in the presence of amendments. However due to the low bioavailability of As in the tailings, the authors concluded that phytoremediation was not a practical option for efficient remediation [53]. In a similar effort, two endemic species from New Caledonia; Geissois pruinosa, a hypernickelophore, and Grevillea exul, a Mn accumulator, were employed for the restoration of mine spoils in the country. Twenty months after plantation, mean Ni concentrations in G. pruinosa reached $1513 \mathrm{mg} \mathrm{kg}^{-1}$, while up to $2000 \mathrm{mg} \mathrm{kg}^{-1} \mathrm{Mn}$ was accumulated by G. exul, underpinning the capacity of these species for mine restoration and ecological restoration [54]. Much recently, a study by Diarra et al. [55] assessed chelate-assisted phytoextraction of multi-metal contaminated soils in Fiji using B. juncea and B. rapa. Although the authors observed that HM accumulation increased in plants treated with biodegradable chelating agents, they concluded that chelate-assisted phytoextraction with both Brassica spp. was highly limited in multi-metal settings, making it an unsuitable option for severely contaminated sites.

These studies have been limited both in scale and reach, therefore failing to elucidate the full potential of phytoremediation for the region. Thus, in lieu of these limitations, it is important to strengthen the approach, appeal and value of phytoremediation studies in the region. The use of native plant species for phytoextraction is often preferred as they are acclimatized to local climatic conditions and seasonal cycles, thus, requiring less management [46]. Vetiver grass (V. zizanioides), introduced from India into Pacific Islands such as Fiji more than 100 years ago and widely distributed in the region today, has been commonly used for water and soil conservation since the 1950s. Studies have demonstrated that Vetiver grass produces large biomass $\left(>100 \mathrm{t} \mathrm{ha}^{-1} \mathrm{yr}^{-1}\right)$, exceedingly tolerates soil and climatic extremes such as prolonged drought, flood, submergence and temperatures $\left(-15\right.$ to $55^{\circ} \mathrm{C}$ ), acidity and alkalinity ( $\mathrm{pH} 3.3$ to 9.5 ), salinity (Electrical Conductivity $47.5 \mathrm{~S} \mathrm{~m}^{-1}$ ) and can accumulate an extensive range of HMs (As, Cd, Cr, $\mathrm{Cu}, \mathrm{Hg}, \mathrm{Ni}, \mathrm{Pb}, \mathrm{Se}$, and $\mathrm{Zn}$ ) [56]. Vetiver is a suitable candidate for phytostabilization since it predominantly accumulates HMs in roots, however, with the application of chelating agents, the plant species has been found to significantly accumulate $\mathrm{Cu}, \mathrm{Zn}$ and $\mathrm{Pb}$ in the aboveground parts [57]. The above properties make Vetiver a choice plant for phytoremediation of HMs and organic wastes.

Constructed wetlands (CW), which are artificial treatment systems engineered to utilize the natural functions of wetland vegetation, water, soil media, and their associated microbial accumulation to treat primary or secondary domestic sewage effluent, have gained considerable global interest as an effective and sustainable management system for contaminated waste water. While CW systems are appealing for their eco-friendly approach and low investment and maintenance costs, their construction and design processes require an interdisciplinary team of experts in chemistry, hydrology, soil science, plant biology, natural resources, environmental management, ecology, environmental engineering, surveying, and project management. There have been so far two documented trials of CW systems to manage and/or treat municipal effluents in PICTs, 


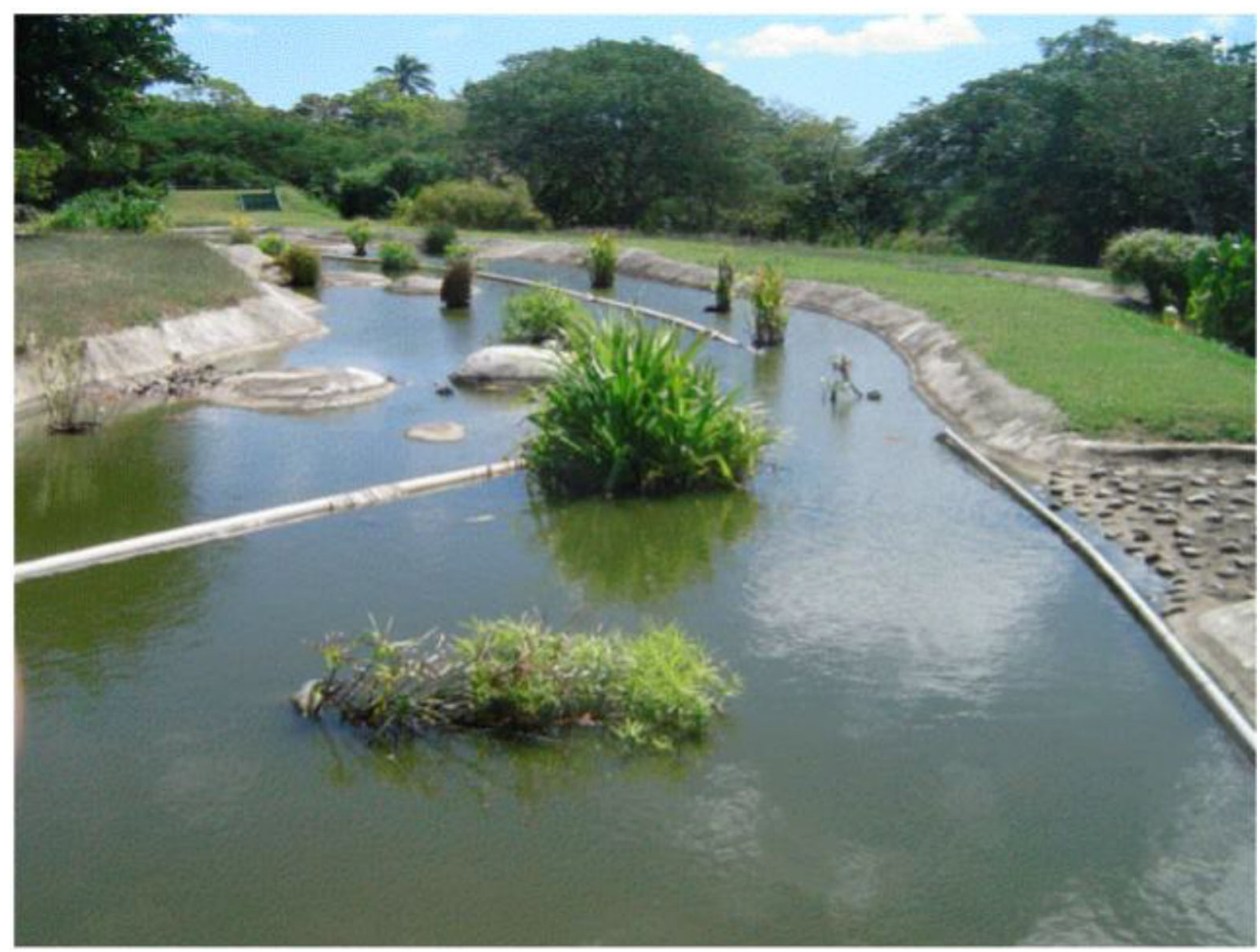

Figure 3. One of a series of three surface-flow constructed wetlands set up in Tangage village, on the Coral Coast of Fiji to receive treated wastewaters recirculated from the adjacent irrigation water storage pond (Photo: Chris Tanner).

both conducted in Fiji. The Wai Bulabula artificial wetlands treatment system, recognized as the first of its kind in Fiji and the wider South Pacific, commenced in 1999 and was developed and funded under the Darwin funded project. The second is a $44 \mathrm{~m}$ horizontal flow CW in Tagaqe village (Figure 3), on the Coral Coast of Fiji, funded by the Packard Foundation, USA and built with technical assistance from the National Institute of Water \& Atmospheric Research (NIWA), New Zealand and The University of the South Pacific [58]. Both projects were designed to protect nutrient-sensitive coral reefs and their associated biodiversity by managing land-based sources of pollution through participatory community approaches. Although largely demonstrative, the Tagaqe wetland achieved removal efficiency for fecal coliform, E.coli, total suspended solids (TSS), and biological oxygen demand (BOD) of over 90\% [58]. The total inorganic nitrogen (TIN) to phosphorus $\left(\mathrm{PO}_{4}-\mathrm{P}\right)$ ratio was 9 and 5 for the untreated influent and the treated effluent, respectively [58].

Although largely proof of concepts, these studies elucidate the potential of macrophytes and CW systems as sustainable options which promote cleaner waters conducive for healthier marine ecosystems, benefiting both local communities and wildlife. Recent studies are exploring constructed wetlands for the treatment of water containing hazardous contaminants, including HMs using rhizofiltration and phytostabilization [59]. Some findings suggest that the specific filter media within CWs; e.g., limestone, lignite, 
activated carbon, peat and leaves, can reduce HM bioavailability through chemical processes including acid volatile sulfide formation and organic carbon binding and sorption [60]. Nonetheless, effective and proven design criteria do not currently exist for HM removal using CWs. The integration and optimization of phytoremediation and constructed wetland technologies might provide enhanced solutions for the management of HMs in the future.

\section{Conclusion}

Phytoremediation technologies provide an integrated solution for treating inorganic and organic pollution, and are inherently well suited for the Pacific Islands considering the favorable tropical conditions which favor the cultivation of a wide diversity of plant species. In addition, the low to medium levels of heavy metal contaminations in most PICTs makes phytoremediation technologies far more viable under concerted and well managed programs. Nonetheless, major bottlenecks currently exist limiting its appeal and feasibility in the region. Perhaps most significant are knowledge gaps and the lack of research interests into natural remediation alternatives in the region. Elsewhere in the advanced countries, regular training of expert and sharing of information regarding best practices for remediation of sites are conducted and facilitated. The absence of such regional platforms and policies in PICTs creates a vacuum in contaminated areas management, therefore fostering such platforms is essential for information and expertise sharing regionally. Furthermore, the inconsistency in policy and poor enforcement by regulatory agencies often considered as another major obstacle preventing a cohesive front for integrated waste management. Regional bodies such as the Secretariat Pacific Regional Programme for the Environment (SPREP) and The South Pacific Commission (SPC) need to develop policies and frameworks to guide and support the application of phytoremediation as well as other nature-based remediation technologies in the region. Lastly, the lack of adequate funding toward the assessment, management and remediation of contaminated areas and wastes has been a major factor hindering research. Due to the relative high cost of remediation projects, regional governments have often avoided the implementation of environmental recommendations. Although these have been aided by international development partners such as the Australian Government and Japan International Cooperation Agency (JICA), poorly-structured and unskilled nodal agencies often fail to meet objectives. Phytoremediation requires a commitment of resources and time, but has the potential to provide a low-cost and environmentally acceptable alternative to conventional remedial technologies at appropriate sites. Consequently, with more research on the applicability of the phytoremediation systems and regional integrated efforts, sustainable management and restoration of contaminated sites in the Pacific Islands will move toward sustainability.

\section{Conflict of interest}

The authors declare that there is no conflict of interest including any financial, personal or other relationships with other people or organizations. 


\section{Funding}

The authors are grateful to The University of the South Pacific for funding through the research office (Vote code: FUND F3216 ORG FST12).

\section{ORCID}

Ivan Diarra (D) http://orcid.org/0000-0003-1565-0295

Krishna Kumar Kotra (D) http://orcid.org/0000-0002-2140-7163

Surendra Prasad (D) http://orcid.org/0000-0003-2001-7937

\section{References}

1. Rai, P. K.; Lee, S. S.; Zhang, M.; Tsang, Y. F.; Kim, K.-H. Heavy Metals in Food Crops: Health Risks, Fate, Mechanisms, and Management. Environ. Int. 2019, 125, 365-385. doi: 10.1016/j.envint.2019.01.067

2. Diarra, I.; Prasad, S. The Current State of Heavy Metal Pollution in Pacific Island Countries: A Review. Appl. Spectrosc. Rev. 2021, 56, 27-51. doi:10.1080/05704928.2020. 1719130

3. SPREP. 2010 Pacific Regional Solid Waste Management Strategy 2010-2015.

4. Burns, T.; Graham, B.; Munro, A.; Wallis, I. 2000 Management of persistant organic pollutants in Pacific Island Countries: Waste and obsolete chemcals and chemically contaminated sites.

5. Reddy, K. R. Technical Challenges to in-Situ Remediation of Polluted Sites. Geotech. Geol. Eng. 2010, 28, 211-221. doi:10.1007/s10706-008-9235-y

6. Wei, Z.; Van Le, Q.; Peng, W.; Yang, Y.; Yang, H.; Gu, H.; Lam, S. S.; Sonne, C. A Review on Phytoremediation of Contaminants in Air, Water and Soil. J. Hazard. Mater. 2021, 403, 123658. doi:10.1016/j.jhazmat.2020.123658

7. Stegmann, R.; Brunner, G.; Calmano, W.; Matz, G. 2013 Treatment of Contaminated Soil: Fundamentals, Analysis, Applications. Springer Science \& Business Media: Berlin, Germany.

8. Wuana, R. A.; Okieimen, F. E. Heavy Metals in Contaminated Soils: A Review of Sources, Chemistry, Risks and Best Available Strategies for Remediation. Ecology 2011, 5, 1-20.

9. Bello, A. O.; Tawabini, B. S.; Khalil, A. B.; Boland, C. R.; Saleh, T. A. Phytoremediation of Cadmium-, Lead- and Nickel-Contaminated Water by Phragmites Australis in Hydroponic Systems. Ecol. Eng. 2018, 120, 126-133. doi:10.1016/j.ecoleng.2018.05.035

10. Ramana, S.; Biswas, A. K.; Ajay Singh, A. B.; Ahirwar, N. K.; Subba Rao, A. Potential of Rose for Phytostabilization of Chromium Contaminated Soils. Ind. J. Plant Physiol. 2013, 18, 381-383. doi:10.1007/s40502-013-0055-6

11. Verbruggen, N.; Hermans, C.; Schat, H. Molecular Mechanisms of Metal Hyperaccumulation in plants. New Phytol. 2009, 181, 759-776. doi:10.1111/j.1469-8137. 2008.02748.x

12. Dürešová, Z.; Šuňovská, A.; Horník, M.; Pipíška, M.; Gubišová, M.; Gubiš, J.; Hostin, S. Rhizofiltration Potential of Arundo Donax for Cadmium and Zinc Removal from Contaminated Wastewater. Chem. Pap. 2014, 68, 1452-1462. doi:10.2478/s11696-014-0610-2

13. Gatliff, E.; Linton, P. J.; Riddle, D. J.; Thomas, P. R. Chapter 23 - phytoremediation of soil and groundwater: Economic benefits over traditional methodologies. In Bioremediation and Bioeconomy, Prasad, M. N. V., Ed., Elsevier, London, UK, pp. 589-608.

14. Zhao, Y.; Mao, G.; Hongxia, H.; Gao, L. Effects of EDTA and EDDS on Heavy Metal Activation and Accumulation of Metals by Soybean in Alkaline Soil. Soil Sediment Contam. 2015, 24, 353-367. doi:10.1080/15320383.2015.962125

15. Baker, A. J. M. Accumulators and Excluders -Strategies in the Response of Plants to Heavy Metals. J. Plant Nutr. 1981, 3, 643-654. doi:10.1080/01904168109362867 
16. Jaffré, T.; Brooks, R. R.; Lee, J.; Reeves, R. D. Sebertia Acuminata: A Hyperaccumulator of Nickel from New Caledonia. Science 1976, 193, 579-580. doi:10.1126/science.193.4253.579

17. Jaffré, T. 1980 Étude Écologique du Peuplement Végétal Des Sols Dérivés de Roches Ultrabasiques en Nouvelle-Calédonie. Office de la recherche scientifique et technique outremer: Paris.

18. Morel, J.-L.; Echevarria, G.; Goncharova, N. 2006 Phytoremediation of Metal-Contaminated Soils. Springer Science \& Business Media: Netherlands.

19. Mao, X.; Han, F. X.; Shao, X.; Guo, K.; McComb, J.; Arslan, Z.; Zhang, Z. Electro-Kinetic Remediation Coupled with Phytoremediation to Remove Lead, Arsenic and Cesium from Contaminated Paddy Soil. . 2016, 125, 16-24. doi:10.1016/j.ecoenv.2015.11.021

20. Chen, J.; Huang, J. Role of Ph in Phytoremediation of Contaminated Soils. In Handbook of Soil Acidity, 1st ed.; CRC Press: Boca Raton, 2003; p 24.

21. Xian, X.; In Shokohifard, G. Effect of $\mathrm{pH}$ on Chemical Forms and Plant Availability of Cadmium, Zinc, and Lead in Polluted Soils. Water. Air. Soil Pollut. 1989, 45, 265-273. doi: 10.1007/BF00283457

22. Yoon, J.; Cao, X.; Zhou, Q.; Ma, L. Q. Accumulation of $\mathrm{Pb}, \mathrm{Cu}$, and $\mathrm{Zn}$ in Native Plants Growing on a Contaminated Florida site. Sci Total Environ. 2006, 368, 456-464. doi:10. 1016/j.scitotenv.2006.01.016

23. Goswami, S.; Das, S. A Study on Cadmium Phytoremediation Potential of Indian Mustard, Brassica Juncea. Int. J. Phytoremediat. 2015, 17, 583-588. doi:10.1080/15226514.2014.935289

24. Rahman, M. M.; Azirun, S. M.; Boyce, A. N. Enhanced Accumulation of Copper and Lead in Amaranth (Amaranthus Paniculatus), Indian Mustard (Brassica Juncea) and Sunflower (Helianthus Annuus). PLoS One 2013, 8, e62941. doi:10.1371/journal.pone.0062941

25. do Nascimento, C. W. A.; Amarasiriwardena, D.; Xing, B. Comparison of Natural Organic Acids and Synthetic Chelates at Enhancing Phytoextraction of Metals from a Multi-Metal Contaminated Soil. Environ. Pollut. 2006, 140, 114-123. doi:10.1016/j.envpol.2005.06.017

26. Purakayastha, T. J.; Viswanath, T.; Bhadraray, S.; Chhonkar, P. K.; Adhikari, P. P.; Suribabu, K. Phytoextraction of Zinc, Copper, Nickel and Lead from a Contaminated Soil by Different Species of Brassica. Int. J. Phytoremediat. 2008, 10, 61-72. doi:10.1080/ 15226510701827077

27. Solhi, M.; Shareatmadari, H.; Hajabbasi, M. A. Lead and Zinc Extraction Potential of Two Common Crop Plants, Helianthus Annuus and Brassica Napus. Water. Air. Soil Pollut. 2005, 167, 59-71. doi:10.1007/s11270-005-8089-7

28. Brunetti, G.; Farrag, K.; Rovira, P. S.; Nigro, F.; Senesi, N. Greenhouse and Field Studies on $\mathrm{Cr}, \mathrm{Cu}, \mathrm{Pb}$ and $\mathrm{Zn}$ Phytoextraction by Brassica Napus from Contaminated Soils in the Apulia Region, Southern Italy. Geoderma 2011, 160, 517-523. doi:10.1016/j.geoderma.2010. 10.023

29. Marchiol, L.; Assolari, S.; Sacco, P.; Zerbi, G. Phytoextraction of Heavy Metals by Canola (Brassica Napus) and Radish (Raphanus sativus) Grown on Multicontaminated Soil. Environ. Pollut. 2004, 132, 21-27. doi:10.1016/j.envpol.2004.04.001

30. Bharagava, R.; Chandra, R.; Rai, V. Phytoextraction of Trace Elements and Physiological Changes in Indian Mustard Plants (Brassica Nigra 1.) Grown in Post Methanated Distillery Effluent (Pmde) Irrigated Soil. Bioresour. Technol. 2008, 99, 8316-8324. doi:10.1016/j.biortech.2008.03.002

31. Marchiol, L.; Fellet, G.; Perosa, D.; Zerbi, G. Removal of Trace Metals by Sorghum bicolor and Helianthus Annuus in a Site Polluted by Industrial Wastes: A Field Experience. Plant Physiol. Biochem 2007, 45, 379-387. doi:10.1016/j.plaphy.2007.03.018

32. Hussain, A.; Amna Kamran, M. A.; Javed, M. T.; Hayat, K.; Farooq, M. A.; Ali, N.; Ali, M.; Manghwar, H.; Jan, F.; Chaudhary, H. J. Individual and Combinatorial Application of Kocuria rhizophila and Citric Acid on Phytoextraction of Multi-Metal Contaminated Soils by Glycine max L. Environ. Exp. Bot. 2019, 159, 23-33. doi:10.1016/j.envexpbot.2018.12.006

33. Davidson, C. M. 2013 Methods for the Determination of Heavy Metals and Metalloids in Soils. In Heavy Metals in Soils: Trace Metals and Metalloids in Soils and Their Bioavailability, Alloway, B. J., Ed. Springer Netherlands: Dordrecht; pp 97-140. 
34. Sneddon, J.; Hardaway, C.; Bobbadi, K. K.; Reddy, A. K. Sample Preparation of Solid Samples for Metal Determination by Atomic Spectroscopy-an Overview and Selected Recent Applications. Appl. Spectrosc. Rev. 2006, 41, 1-14. doi:10.1080/05704920500385445

35. Anugrahwati, M.; Falahudin, A.; Anas, A. K. Comparative Analysis of Dry Ashing and Wet Digestion Methods for Determination of $\mathrm{Pb}$ Metal in Tobacco Leaves. AIP Conf. Proc. 2020, 2229, 030040.

36. Cristache, C.-I.; Comero, S.; Locoro, G.; Fissiaux, I.; Alonso Ruiz, A.; Toth, G.; Gawlik, B. 2014 Comparative study on open system digestion vs. microwave-assisted digestion methods for trace element analysis in agricultural soils. (EUR - Scientific and Technical Research Reports) Available at: https://publications.jrc.ec.europa.eu/repository/handle/111111111/ 31670. (accessed January 16 2021).

37. Machado, R. C.; Andrade, D. F.; Babos, D. V.; Castro, J. P.; Costa, V. C.; Sperança, M. A.; Garcia, J. A.; Gamela, R. R.; Pereira-Filho, E. R. Solid Sampling: advantages and Challenges for Chemical Element Determination-a Critical Review. J. Anal. At. Spectrom. 2020, 35, 54-77. doi:10.1039/C9JA00306A

38. Canha, N.; Freitas, M. C.; Anawar, H. M.; Dionísio, I.; Dung, H. M.; Pinto-Gomes, C.; Bettencourt, A. Characterization and Phytoremediation of Abandoned Contaminated Mining Area in Portugal by INAA. J. Radioanal. Nucl. Chem. 2010, 286, 577-582. doi:10. 1007/s10967-010-0780-5

39. Carvalho, G. G. A. d.; Guerra, M. B. B.; Adame, A.; Nomura, C. S.; Oliveira, P. V.; Carvalho, H. W. P.; de Santos, D.; Nunes, L. C.; Krug, F. J. Recent Advances in LIBS and XRF for the Analysis of Plants. J. Anal. At. Spectrom. 2018, 33, 919-944. doi:10.1039/ C7JA00293A

40. Neagu, D.; Arduini, F.; Quintana, J. C.; Di Cori, P.; Forni, C.; Moscone, D. Disposable Electrochemical Sensor to Evaluate the Phytoremediation of the Aquatic Plant Lemna Minor 1. toward $\mathrm{Pb}(2+)$ and/or $\mathrm{Cd}(2+)+$. Environ. Sci. Technol. 2014, 48, 7477-7485. doi: $10.1021 /$ es500675x

41. Nečemer, M.; Kump, P.; Ščančar, J.; Jaćimović, R.; Simčič, J.; Pelicon, P.; Budnar, M.; Jeran, Z.; Pongrac, P.; Regvar, M.; Vogel-Mikuš, K. Application of X-Ray Fluorescence Analytical Techniques in Phytoremediation and Plant Biology Studies. Spectrochim. Acta, Part B. 2008, 63, 1240-1247. doi:10.1016/j.sab.2008.07.006

42. Gutiérrez-Ginés, M. J.; Pastor, J.; Hernández, A. J. Assessment of Field Portable X-Ray Fluorescence Spectrometry for the in Situ Determination of Heavy Metals in Soils and Plants. Environ. Sci. Process. Impacts. 2013, 15, 1545-1552. doi:10.1039/c3em00078h

43. Jin, M.; Yuan, H.; Liu, B.; Peng, J.; Xu, L.; Yang, D. Review of the Distribution and Detection Methods of Heavy Metals in the Environment. Anal Methods. 2020, 12, 5747-5766. doi:10.1039/d0ay01577f

44. Hussain, C. M.; Keçili, R. Emerging Techniques for Environmental Analysis. In Modern Environmental Analysis Techniques for Pollutants, Elsevier, 2020; pp 223-251. doi:10.1016/ C2018-0-01639-4

45. Rathod, P. H.; Rossiter, D. G.; Noomen, M. F.; Meer, F. D. v d. Proximal Spectral Sensing to Monitor Phytoremediation of Metal-Contaminated Soils. Int. J. Phytoremediat. 2013, 15, 405-426. doi:10.1080/15226514.2012.702805

46. Sarma, H. Metal Hyperaccumulation in Plants: A Review Focusing on Phytoremediation Technology. J. Environ. Sci. Technol. 2011, 4, 118-138. doi:10.3923/jest.2011.118.138

47. Shiomi, N., Ed. 2018 Advances in Bioremediation and Phytoremediation. IntechOpen: London, UK.

48. Sheoran, V.; Sheoran, A. S.; Poonia, P. Factors Affecting Phytoextraction: A Review. Pedosphere 2016, 26, 148-166. doi:10.1016/S1002-0160(15)60032-7

49. Ent, A. v d.; Baker, A. J. M.; Reeves, R. D.; Pollard, A. J.; Schat, H. Hyperaccumulators of Metal and Metalloid Trace Elements: Facts and Fiction. Plant Soil 2013, 362, 319-334. doi: 10.1007/s11104-012-1287-3 
50. Shen, X.; Chi, Y.; Xiong, K. The Effect of Heavy Metal Contamination on Humans and Animals in the Vicinity of a Zinc Smelting Facility. Plos One 2019, 14, e0207423. doi:10. 1371/journal.pone.0207423

51. Rungwa, S.; Arpa, G.; Sakulas, H.; Harakuwe, A.; Timi, D. Phytoremediation - an EcoFriendly and Sustainable Method of Heavy Metal Removal from Closed Mine Environments in Papua New Guinea. Procedia Earth and Planetary Science 2013, 6, 269-277. doi:10.1016/j.proeps.2013.01.036

52. Mani, J.; Maata, M.; Mani, F. S. Sewage Sludge Heavy Metal Analysis and Agricultural Prospects for Fiji. RACI Congress: Melbourne, Australia, 2017.

53. Ko, B.-G.; Anderson, C. W. N.; Bolan, N. S.; Huh, K.-Y.; Vogeler, I. Potential for the Phytoremediation of Arsenic-Contaminated Mine Tailings in Fiji. Soil Res. 2008, 46, 493-501. doi:10.1071/SR07200

54. Losfeld, G.; Mathieu, R.; L'Huillier, L.; Fogliani, B.; Jaffré, T.; Grison, C. Phytoextraction from Mine Spoils: insights from New Caledonia. Environ. Sci. Pollut. Res. Int. 2015, 22, 5608-5619. doi:10.1007/s11356-014-3866-8

55. Diarra, I.; Kotra, K. K.; Prasad, S. Assessment of Biodegradable Chelating Agents in the Phytoextraction of Heavy Metals from Multi-Metal Contaminated Soil. Chemosphere 2020, 128483. doi:10.1016/j.chemosphere.2020.128483

56. Danh, L. T.; Truong, P.; Mammucari, R.; Tran, T.; Foster, N. Vetiver Grass, Vetiveria Zizanioides: A Choice Plant for Phytoremediation of Heavy Metals and Organic Wastes. Int. J. Phytoremediation. 2009, 11, 664-691. doi:10.1080/15226510902787302

57. Lou, L. Q.; Ye, Z. H.; Wong, M. H. Solubility and Accumulation of Metals in Chinese Brake Fern, Vetiver and Rostrate Sesbania Using Chelating Agents. Int. J. Phytoremediat. 2007, 9, 325-343. doi:10.1080/15226510701475778

58. Taloiburi, E. J. An Evaluation of the Effects of Wastewater Treatment Initiatives on Water Quality in Coastal Waters along the Coral Coast, Southwest Viti Levu, Fiji Islands. MSc Thesis, The University of the South Pacific, Fiji, 2009.

59. Lizama-Allende, K.; Ayala, J.; Jaque, I.; Echeverría, P. The Removal of Arsenic and Metals from Highly Acidic Water in Horizontal Subsurface Flow Constructed Wetlands with Alternative Supporting Media. J. Hazard. Mater. 2021, 408, 124832 doi:10.1016/j.jhazmat. 2020.124832

60. Obarska-Pempkowiak, H.; Klimkowska, K. Distribution of Nutrients and Heavy Metals in a Constructed Wetland System. Chemosphere 1999, 39, 303-312. doi:10.1016/S00456535(99)00111-3 